\title{
TELLO, César (Coord. y Comp.) Epistemologías de la Política Educativa: posicionamentos, perspectivas y enfoques. Campinas: Mercado de Letras, 2013. 614 p.
}

\section{Por Claudia Regina Baukat Silveira Moreira}

Constituída em 2011 por pesquisadores brasileiros e argentinos, a ReLePe - RedLatinoamericana de EstudiosEspistemológicosen Política Educativa tem notabilizado-se pela preocupação teórica relativa às pesquisas em Políticas Educacionais. A partir desse ponto de aglutinação, César Tello, diretor da ReLePe, organizou esse livro que inicia com uma espécie de manifesto de sua autoria intitulado "Las epistemologias de la Política Educativa - notas históricas y epistemológicas sobre el campo."

O artigo inicia com a constatação de que, diante da chamada crise das Ciências Humanas (decorrente dos impasses da própria noção de Modernidade e suas meta-narrativas, cuja pretensão é a construção de explicações universalizáveis), a pesquisa em Políticas Educacionais tem se caracterizado pela ênfase no método em detrimento da teoria. Em outras palavras: o pesquisador não demarca precisamente o lugar de onde fala, qual o viés teórico de sua pesquisa. Ponto de partida para os demais artigos do livro, que possui como finalidade induzir o debate, apontar limites e potencialidades do campo, a noção de Epistemologias (no plural) das Políticas Educacionais apresenta-se enquanto uma exigência de um campo cujos pesquisadores têm expressado a necessidade de se apropriar dos conhecimentos produzidos nas Ciências Humanas, a fim de marcar a clivagem entre as figuras do "acadêmico" e a do "consultor".

Dividido em duas partes, o livro tem a pretensão de cobrir inúmeras perspectivas teóricas e suas interfaces metodológicas. Na primeira parte, "Perspectivas epistemológicas y enfoques epismetodológicos para lainvestigaciónen Política Educativa", seus quinze capítulos cobrem um amplo espectro de teorias. Alguns textos, como os de Mónica Eva Pini (El análisis crítico del discurso (ACD). Aspectos teóricos y metodológicos enlainvestigación de Políticas Educativas), de Gisele Masson e Jefferson Mainardes (Lascontribuciones de la perspectiva marxista para lainvestigación sobre Políticas Educativas) possuem a preocupação de apresentar ao leitor a articulação entre determinadas teorias e as possibilidades de transposição delas para o campo das Políticas Educacionais. Há em comum nesses textos o cuidado com a adequada articulação entre o horizonte epistemológico e o fazer da pesquisa, aquilo que Tello chama de Epistemetodologia. Outros textos, como o de Silvia Novick de Senén González e Isabel Vilella Paz (Las Políticas Educativas como textos y como discursos. El enfoque de Stephen Ball) e o de Graciela Morgade (Políticas Educativas y relaciones de sexo-género) apresentam dados de pesquisa a partir de uma análise epistemetodológica, o que pode servir de inspiração àqueles que encontram dificuldade em articular seus objetos de pesquisa aos referenciais teóricos.

A segunda parte, "Reflexiones epistemológicas e epistemetodológicas para lainvestigaciónen Política Educativa", é composta por onze textos de extensão menor, que apresentam reflexões mais pontuais sobre a temática. Dessa forma, Pedro Flores Crespo reafirma a pertinência acadêmica do campo, a partir do conceito de políticas e sua importância para a análise da realidade latino-americana. António 
Teodoro defende que a marca distintiva dos estudos epistemológicos em Políticas Educacionais é a sua transdisciplinaridade, verificável pelo histórico de sua constituição. Dermeval Saviani realiza a aproximação entre a Ciência Política e a Pedagogia, partindo da noção (extraída de Norberto Bobbio) de que a primeira é uma ciência prática. Carlos Alberto Torres e José Eustáquio Romão, cada qual em seu texto, partem do viés da Pedagogia do Oprimido, contribuição de Paulo Freire, como possibilidade teórica do campo.

O posfácio, assinado por Maria de Lourdes Pinto de Almeida, reafirma os propósitos do livro: provocar o debate e estimular a realização de pesquisas tanto no âmbito da graduação quanto da pós-graduação. Para além disso, o texto chama a atenção para o fato de que a pesquisa em Políticas Educacionais deve demarcar precisamente seus paradigmas, pois isso representa um contraponto necessário à tendência vigente que, ao enfatizar a metodologia, supostamente neutra, colocaria a produção do conhecimento a serviço do "oportunista abstracto", o capital (e aqui, por óbvio, a autora assume um viés marxista).

Em que pese o fato de que os autores confiram tratamentos bastante distintos à temática proposta em seus textos, o livro apresenta o mérito inequívoco de demarcar uma preocupação relativamente recente e, acima de tudo, contemplar várias perspectivas. Isso apenas reafirma o propósito da constituição da ReLePe e seu alinhamento à uma característica tão cara a nossos tempos: o respeito pela pluralidade e diversidade de posicionamentos teóricos. Como em diversas passagens se reafirma, a grande questão é a explicitação dos lugares de onde se fala. Isso impõe à comunidade acadêmica a necessidade de adensamento teórico, derivado do estudo e do debate. A teoria é, pois, o instrumento intelectual por excelência daqueles que pretendem compreender o Humano com o rigor que a Ciência exige. 